\title{
A new genus and species of uncertain phylogenetic position within the family Hydrobiidae (Caenogastropoda, Truncatelloidea) discovered in Tunisian springs
}

\author{
Noureddine KHALLOUFI ${ }^{1}$, Mustapha BÉJAOUI ${ }^{2} \&$ Diana DELICADO ${ }^{3, *}$ \\ 1,2 University of Carthage - Environmental Biomonitoring Laboratory (Group of Hydrobiology), \\ Faculty of Sciences of Bizerte - Zarzouna 7021, Tunisia. \\ ${ }^{3}$ Justus Liebig University Giessen, Department of Animal Ecology \& Systematics, \\ Heinrich-Buff-Ring 26-32 IFZD, 35392 Giessen, Germany. \\ * Corresponding author: didelicado@gmail.com \\ ${ }^{1}$ Email: khalnour2003@yahoo.fr \\ 2Email: bejaouimustapha@yahoo.com \\ ${ }^{1}$ urn:1sid:zoobank.org:author:50828922-AFD9-41DF-93BC-C5F8D15264D6 \\ ${ }^{2}$ urn:1sid:zoobank.org:author:3A28BD3D-F5A6-45F5-B807-33EFC2759216 \\ ${ }^{3}$ urn:1sid:zoobank.org:author:52A050CB-4AE4-4EEF-8D5E-B508A0EC5AB2
}

\begin{abstract}
The species richness of the aquatic (non-marine) gastropod family Hydrobiidae Stimpson, 1865 reaches its peak in the European region partly because other areas, such as North Africa, remain to be extensively surveyed. Most of the hydrobiid species described in North Africa have been ascribed to the subfamilies Pseudamnicolinae, Hydrobiinae and the genus Mercuria. Little is known about the presence of other hydrobiid subfamilies. This study examines several specimens of gastropods collected from two springs in Tunisia. Based on a comprehensive literature review and rigorous anatomical and molecular comparisons with known species from North Africa, Europe and Asia Minor of similar morphology, we here describe a new genus, Bullaregia gen. nov., and new species Bullaregia tunisiensis gen. et sp. nov. Although the shell shape of this Tunisian species resembles that of European hydrobiid genera such as Belgrandiella, it differs in other anatomical structures (i.e., penis with a glandular strap-like lobe, and two seminal receptacles, SR1 pedunculate, SR2 sessile and less developed). Using maximum likelihood and Bayesian approaches, phylogenetic relationships inferred from mtCOI sequences point to an independent evolutionary lineage for this new taxon outside Belgrandiella and other known hydrobiid subfamilies.
\end{abstract}

Keywords. Freshwater snails, Western Palaearctic, North Africa, anatomy, Belgrandiella.

Khalloufi N., Béjaoui M. \& Delicado D. 2017. A new genus and species of uncertain phylogenetic position within the family Hydrobiidae (Caenogastropoda: Truncatelloidea) discovered in Tunisian springs. European Journal of Taxonomy 328: 1-15. https://doi.org/10.5852/ejt.2017.328 


\section{Introduction}

The aquatic (non-marine) gastropod family Hydrobiidae Stimpson, 1865 (sensu Wilke et al. 2013) occurs mainly in the Western Palaearctic, Nearctic, northern Neotropic and South Africa. In Europe, a high species richness has been described for this family. However, this is likely the consequence of an underreporting of the hydrobiid fauna living in other regions such as North Africa. Based only on shell characters, Van Damme (1984) and Kristensen (1985) reported the presence in North Africa of seven European genera of Hydrobiidae sensu lato (i.e., Belgrandia Bourguignat, 1869; Bythinella Moquin-Tandon, 1855; Hadziella Kuscer, 1932; Horatia Bourguignat, 1887; Hydrobia Hartmann, 1821; Peringia Paladilhe, 1874 and Pseudamnicola Paulucci, 1878) and one endemic genus (i.e., Heideella Backhuys and Boeters, 1974). More recently, Ghamizi et al. (1999) and Bodon et al. (1999) added other species and genera to the Moroccan Hydrobiidae list, mostly stygobiont species. However, despite these important discoveries, most studies have provided mere descriptions of shell morphology without focusing on anatomical structures. In prior work, we confirmed that by adding anatomical and molecular data to these shell-based identifications, the reliability of generic classification could be much improved (Delicado et al. 2016).

In Tunisia, a few Hydrobiidae species have been shell-determined over the past centuries (Bourguignat 1860, 1864; Issel 1880; Debeaux 1863; Letourneux \& Bourguignat 1887; Pallary 1921, 1923; Seurat 1921, 1934). So far, the most relevant study of this family in Tunisia was that by Boeters (1976) who listed 28 species belonging to three genera: Pseudamnicola, Hydrobia and Mercuria Boeters, 1971. Based on these descriptions, an extensive survey in the past ten years of freshwater superficial and subterranean malacofauna has revealed Hydrobiidae to be among the most species- and population rich families in the country. In contrast, Tunisia's subterranean aquatic fauna has recently received much less attention, although this region (especially NW Tunisia) has numerous wells and springs, and some caves. Early studies examining the general subterranean and spring fauna of Tunisia were those by Seurat $(1921,1934)$ and Debeaux $(1863)$, who discovered only a few gastropod and two isopod species in these habitats. One example of Hydrobiidae is the species 'Hydrobia' nana (Terver, 1939) found by Debeaux (1863) in springs of Algeria and two localities of northern Tunisia. The few more recent surveys have detected new records and new species of phreatic microgastropods (such as Pseudamnicola) as well as other stygobiont or eustygophilous taxa such as worms (Charni et al. 2004; Harrath et al. 2001, 2004) and crustaceans (Toumi et al. 2013). However, to our knowledge true stygobiont species of Hydrobiidae inhabiting Tunisian groundwaters have been rarely reported. In consequence, there are no appropriate references for the straightforward identification of Tunisian groundwater species.

In summary, we could argue that the picture of hydrobiid species richness in North Africa is still very incomplete, and that only surface-water genera of the subfamilies Pseudamnicolinae, Hydrobiinae and the genus Mercuria have been more intensively studied. This situation prompted a new survey of ground- and surface waters to search for possible endemic forms in Tunisia. The collection of specimens obtained contains some unknown Hydrobiidae species. We here describe one of these species and assign it to the genus Bullaregia gen. nov. As the shell shape of this new genus resembles that of the European Belgrandiella (subfamily Belgrandiellinae), we conducted a systematic review using both molecular and morphological methods. Our results indicate this taxon is a distinct hydrobiid genus characterized by a particular set of anatomical characters (not known for other subfamilies) and suggest its uncertain position within the Hydrobiidae phylogeny.

\section{Material and methods}

The material was found at two localities in northwestern Tunisia: Aïn Gnaa (Jendouba, northwestern Tunisia), 36.5583 N, 8.74667 E, alt. 206 m a.s.l.; Djebba (Beja, northwestern Tunisia), 36.47125 N, 9.0997223 E, alt. $342 \mathrm{~m}$ a.s.l. (Fig. 1). Live specimens were collected within the river substrate with a 
sieve of $300 \mu \mathrm{m}$ mesh cloth. The samples were preserved in $70 \%$ ethanol and sorted in the laboratory under an optical stereo microscope (MOTIC-ST-39 Series). Anatomical characteristics (genitalia, radula, stomach and gill) were studied under the stereo microscope and compared with other described forms from North Africa, Europe and Asia Minor. Morphological characters were described based on the standard terminology of Hershler \& Ponder (1998). Shell measurements were made with an eye-piece micrometer under the stereo microscope. The sex of the holotype was not examined in order to keep the shell intact. Photographs were taken with a camera system and a digital adapter. The type material is deposited in the Collection of Molluscs of the Museo Nacional de Ciencias Naturales de Madrid (MNCN).

Our phylogenetic analyses included one specimen of Bullaregia tunisiensis gen. et sp. nov. from a spring in Djebba (type locality) and 22 hydrobiid representatives of other European genera whose shell morphology resembles the new African hydrobiid here discovered (Table 1). Genomic DNA was extracted using the CTAB protocol of Wilke et al. (2006). The mitochondrial fragment of cytochrome $c$ oxidase subunit I (COI) was amplified with the primers LCO1490 (Folmer et al. 1994) and COR722b (Wilke \& Davis 2000). The cycling sequence conditions were as described in Schreiber et al. (2012). Final PCR products were sequenced in an ABI 3730 XL sequencer (Life Technologies, Carlsbad, CA, USA) using a Big Dye Terminator kit v. 3.1 (Life Technologies). New sequences were deposited in GenBank (Table 1).

Amplified sequences were edited in Sequencher 4.6 (Gene Codes, Ann Arbor, MI). The protein-coding mitochondrial COI sequence was unambiguously aligned in PAUP* 4.0a123 (Swofford 2002) together with sequences of other hydrobiid species obtained from GenBank (Table 1). As Wilke et al. (2013) found little saturation among COI sequences of hydrobiids and other sister families, we did not test for saturation in our alignment. Prior to the species tree reconstruction, we searched for closely related taxa

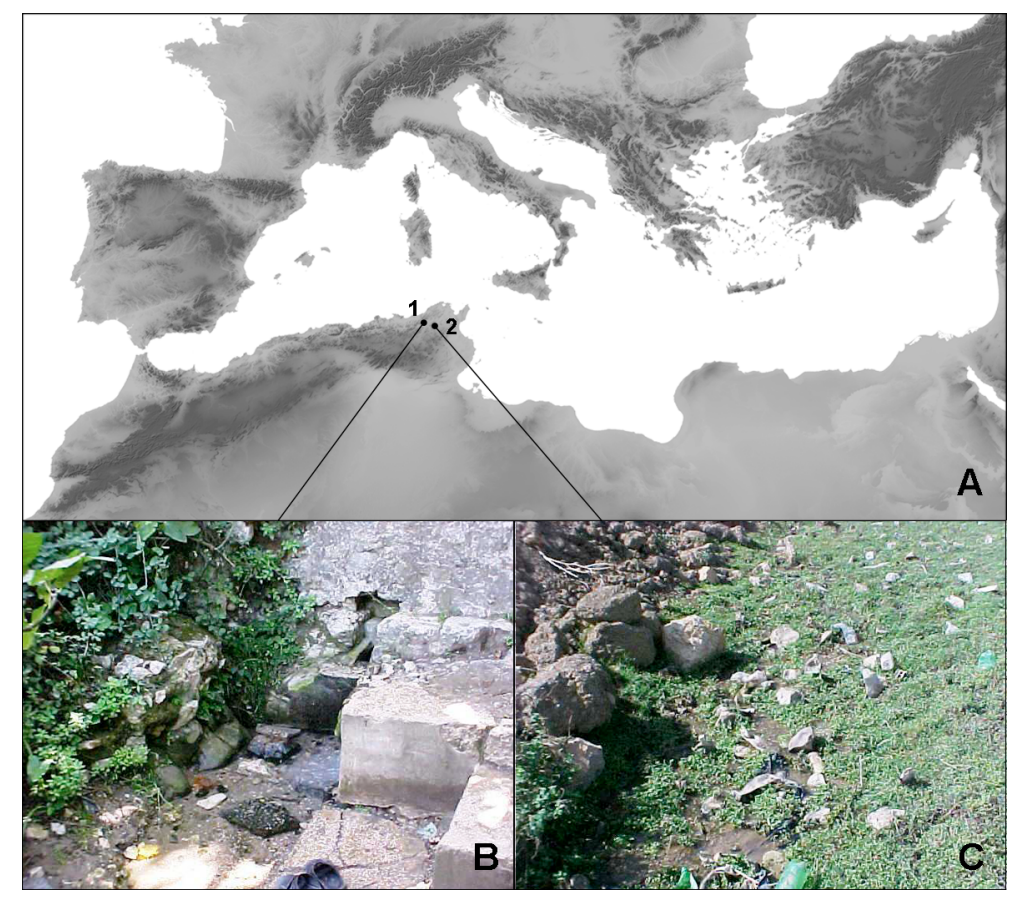

Fig. 1. Map and photographs of the studied sampling sites. A. Map showing the geographic distribution of Bullaregia tunisiensis sp. nov. B. Aïn Gnaa (Bulla-régia, Jendouba). C. Djebba (Thibar, Beja). 
on GenBank using BLASTN 2.3.1 (Zhang et al. 2000) against the National Center for Biotechnology Information (NCBI) nucleotide database. As no high sequence identity with other European and/or African hydrobiid was identified (one hundred contigs showed BLASTN $\%$ identity $\leq 86 \%$, most of them corresponding to species of the American hydrobiid genus Pyrgulopsis Call \& Pilsbry, 1886), we compared our fragments to sequences from similar species which potentially may belong to the same genus or subfamily.

Phylogenetic relationships were inferred by Bayesian-inference (BI) and Maximum Likelihood (ML). For these methods, Partition Finder 1.1.1. (Lanfear et al. 2012) was used to select the best-fit model of nucleotide evolution by codon position within our COI dataset, implementing corrected Akaike's information criterion (AICc; Akaike 1974; Sugiura 1978; Hurvich \& Tsai 1989) for model selection and RAxML-HPC v.8 (Stamatakis 2014) for likelihood estimation. BI was performed through two independent runs of four Metropolis-coupled Markov chains in MrBayes 3.1.2 (Huelsenbeck 2000; Huelsenbeck \& Ronquist 2001), using 2.5 million generations each and a sample frequency of 1000 . The analysis was terminated when the average standard deviation of split frequencies was less than 0.01 , indicating that the runs reached convergence. The first $10 \%$ sampled trees were discarded as burn-in. Partitioned ML analysis was undertaken using RAxML-HPC v.8 on the computer cluster of the CyberInfrastructure for Phylogenetic Research project (CIPRES, www.phylo.org). Clade support for the ML phylogeny was assessed by nonparametric bootstrapping (Felsenstein 1985) using 100 pseudoreplicates, and by posterior probabilities (BPPs) for the BI.

$$
\begin{aligned}
& \text { Abbreviations } \\
& \text { AH }=\text { Aperture height } \\
& \mathrm{AW}=\text { Aperture width } \\
& \mathrm{H}=\text { Height } \\
& \mathrm{W}=\text { Width }
\end{aligned}
$$

\section{Results}

The alignment of COI sequences yielded 648 bp for which Partition Finder identified TrN (Tamura \& Nei 1993) + I (invariable sites) + G (rate variation among sites), F81 (Felsenstein 1981) + I and GTR (Tavare 1986$)+\mathrm{I}+\mathrm{G}$ as the best-fit models of nucleotide substitution for the $1^{\text {st }}, 2^{\text {nd }}$ and $3^{\text {rd }}$ codon position, respectively. Average base frequencies were $31.2 \% \mathrm{~A}, 13.5 \% \mathrm{C}, 12.1 \% \mathrm{G}$ and $43.2 \% \mathrm{~T}$. ML and BI gave rise to similar topologies and both showed Bullaregia gen. nov. outside the subfamilies to which this genus could belong (Fig. 2). These subfamilies, i.e., Belgrandiellinae, Belgrandiinae and Horatiinae on the one hand, and Islamiinae on the other, formed two different monophyletic groups well supported by ML and BI (bootstrap value $=70$ and $72 \%$, and BPP $=0.99$ and 0.99 , respectively). Though the exact phylogenetic position of Bullaregia gen. nov. remains unclear, both analyses showed a distant relationship between this and the European genus Belgrandiella (uncorrected pairwise distances of $17.1 \%)$. Morphological data also supported these distant relationships. Differences in shell and anatomical structures between Bullaregia gen. nov. and other hydrobiid genera mentioned above are described in the following section. 
Table 1. Taxa included in the molecular analyses with their corresponding locality names, GenBank accession numbers and original references.

\begin{tabular}{|c|c|c|c|}
\hline Taxon & Locality & $\begin{array}{c}\text { GenBank \# } \\
\text { COI }\end{array}$ & Original reference \\
\hline \multicolumn{4}{|c|}{ Outgroup } \\
\hline Mercuria similis & $\begin{array}{l}\text { Italy, Friuli-Venetia-Julia, Udine, } \\
\text { Aquileia, Canale Panigai }\end{array}$ & AF367646 & Wilke et al. 2001 \\
\hline Pseudamnicola lucensis & $\begin{array}{l}\text { Italy, Tuscany, Bagni di Lucca, } \\
\text { Bagni Caldi, thermal spring }\end{array}$ & AF367651 & Wilke et al. 2001 \\
\hline \multicolumn{4}{|c|}{$\begin{array}{ll}\text { Ingroup } \\
\end{array}$} \\
\hline Agrafia wiktori & $\begin{array}{l}\text { Greece, Evrytania, Agrafa } \\
\text { mountains }\end{array}$ & JF906762 & Szarowska \& Falniowski 2011 \\
\hline Alzoniella finalina & $\begin{array}{l}\text { Italy, Liguria, Savona, Molino, } \\
\text { spring at the Porra river }\end{array}$ & AF367650 & Wilke et al. 2001 \\
\hline Anagastina zetaevalis & $\begin{array}{l}\text { Montenegro, Vranicke, spring at } \\
\text { the Zeta river }\end{array}$ & EF070616 & Szarowska 2006 \\
\hline Avenionia brevis & $\begin{array}{l}\text { France, Gard, spring of the } \\
\text { fountain of St.Victor-La Coste }\end{array}$ & AF367638 & Wilke et al. 2001 \\
\hline Belgrandia thermalis & $\begin{array}{l}\text { Italy, Tuscany, Pisa, S. Giuliano } \\
\text { Terme, thermal channel }\end{array}$ & AF367648 & Wilke et al. 2001 \\
\hline Belgrandiella kusceri & Slovenia, spring of Rakek & JX970610 & Wilke et al. 2013 \\
\hline Boleana umbilicata & $\begin{array}{l}\text { Slovenia, Močilnik, the spring of } \\
\text { the Ljubljanica river }\end{array}$ & JX982795 & Falniowski \& Szarowska 2012 \\
\hline Bullaregia tunisiensis gen. et sp. nov. & $\begin{array}{l}\text { Tunisia, Province Béja, a spring } \\
\text { in Djebba }\end{array}$ & KX821683 & present study \\
\hline Dalmatinella fluviatilis & $\begin{array}{l}\text { Croatia, Jankovica Buk } \\
\text { waterfalls, the Zrmanja River }\end{array}$ & KC344541 & Falniowski \& Szarowska 2013 \\
\hline Daphniola graeca & Greece, Dafne spring & EF070618 & Szarowska 2006 \\
\hline Fissuria boui & $\begin{array}{l}\text { France, Alpes Maritimes, } \\
\text { Peymeinade, spring near La } \\
\text { Prouveresse. }\end{array}$ & AF367654 & Wilke et al. 2001 \\
\hline Graecoarganiella parnassiana & $\begin{array}{l}\text { Greece, Parnassus mountains, } \\
\text { south of Eptalofos }\end{array}$ & JN202348 & Falniowski \& Szarowska 2011 \\
\hline Graziana alpestris & $\begin{array}{l}\text { Italy, Liguria, Savona, Molino, } \\
\text { spring at the Porra River }\end{array}$ & AF367641 & Wilke et al. 2001 \\
\hline Grossuana codreanui & $\begin{array}{l}\text { Romania, from a spring close to } \\
\text { the lake Techirghiol }\end{array}$ & EF061919 & Szarowska et al. 2007 \\
\hline Hauffenia tellinii & $\begin{array}{l}\text { Italy, Friuli-Venetia Julia, } \\
\text { Gorizia, spring of the Isonzo } \\
\text { River near Sagrado }\end{array}$ & AF367640 & Wilke et al. 2001 \\
\hline Horatia klecakiana & $\begin{array}{l}\text { Croatia, N of Kučice, Studenci } \\
\text { spring, in the valley of the Cetina } \\
\text { river }\end{array}$ & KJ159128 & Szarowska \& Falniowski 2014 \\
\hline Islamia piristoma & $\begin{array}{l}\text { Italy, Liguria, La Spezia, spring } \\
\text { on the right bank of Magra river }\end{array}$ & AF367639 & Wilke et al. 2001 \\
\hline Pauluccinella minima & Italy, S. Egidio, Lago di Piediluco & JX970612 & Wilke et al. 2013 \\
\hline Radomaniola callosa & $\begin{array}{l}\text { Italy, Abruzzo, Caramanico } \\
\text { Terme, stream on the left bank of } \\
\text { Orfento river }\end{array}$ & AF367649 & Wilke et al. 2001 \\
\hline Sadleriana flumminensis & $\begin{array}{l}\text { Croatia, Jadro River at Solin near } \\
\text { Split }\end{array}$ & AF367647 & Wilke et al. 2001 \\
\hline Trichonia kephalovrissonia & Greece, Termos & EF070619 & Szarowska 2006 \\
\hline
\end{tabular}


Phylum Mollusca Cuvier, 1795

Class Gastropoda Cuvier, 1795

Superorder Caenogastropoda Cox, 1960

Superfamily Truncatelloidea Gray, 1840

Family Hydrobiidae Stimpson, 1865

Genus Bullaregia gen. nov. urn:1sid:zoobank.org:act:93209E6C-8DBC-4869-BAAD-FA4692D5FAB1

\section{Type species}

Bullaregia tunisiensis sp. nov., by present designation.

\section{Diagnosis}

Shell ovate-conic, penultimate whorl tall relative to remaining whorls; aperture pyriform, angled on top; umbilicus closed by inner lip. Operculum corneous, yellowish, thin, pliable, ellipsoidal, paucispiral with submarginal nucleus. One pair of basal cusps on radular central tooth. Ctenidium bearing welldeveloped gill filaments. Presence of bursa copulatrix; unpigmented renal oviduct with a pouch at the end of the coiled section; two seminal receptacles, SR1 elongate and pedunculate, SR2 globular, sessile and less developed. Strap-like penis attached to the neck behind the right eye, with one dorsal, strap-like glandular lobe.

\section{Etymology}

Referring to the archeological site Bulla Regia, the region where the genus was found; gender feminine.

\section{Remarks}

This genus differs from conchologically similar genera from Europe (e.g., Belgrandiella, Terranigra Radoman, 1978 and Litthabitella Boeters, 1970) and Central Asia (e.g., Chirgisia Glöer, Boeters \& Pešić, 2015) in bearing a strap-like penis (tapered in Belgrandiella, Terranigra and Chirgisia, but broadly triangular in Litthabitella), with one dorsal glandular lobe (absent in all the aforementioned genera) (see Radoman 1983; Szarowska 2006; Glöer et al. 2014). Bullaregia gen. nov. resembles Terranigra and Litthabitella in having two seminal receptacles (none and one in Chirgisia and Belgrandiella, respectively), but they are distinguished by their globular shape (elongate in Terranigra and Litthabitella), and in the position and absence of the duct. Bullaregia gen. nov. conforms to Litthabitella in the radula features, but differs from Belgrandiella in the number of basal cusps on the radular central tooth (two pairs in the latter) (see Szarowska 2006).

Based on molecular and morphological data, Szarowska (2006) tentatively classified Litthabitella within the family Assimineidae (outside Hydrobiidae), which suggests a large genetic distance between this genus and Bullaregia gen. nov. Moreover, our genetic findings indicated that Bullaregia gen. nov. and Belgrandiella differ from each other by $17.1 \%$ COI p-distances.

Bullaregia tunisiensis sp. nov. urn:Isid:zoobank.org:act:BDCEEEDE-8926-4D4C-93B0-9DE6AF75A7DF

Figs $3-5$

\section{Diagnosis}

Shell 1.8 to $2.1 \mathrm{~mm}$ high, yellowish; central radular tooth formula $6-\mathrm{C}-6 / 1-1$; ovoid bursa copulatrix, with a duct longer than bursa; two seminal receptacles, SR1 elongate and pedunculate, SR2 globular 
and sessile; prostate gland about $0.45 \mathrm{~mm}$ ovate in section, penis strap-like, with a dorsal, strap-like glandular lobe, and distal end tapered and greyish pigmented.

\section{Etymology}

The species epithet tunisiensis is an adjectival toponym that refers to Tunisia, where the species was found.

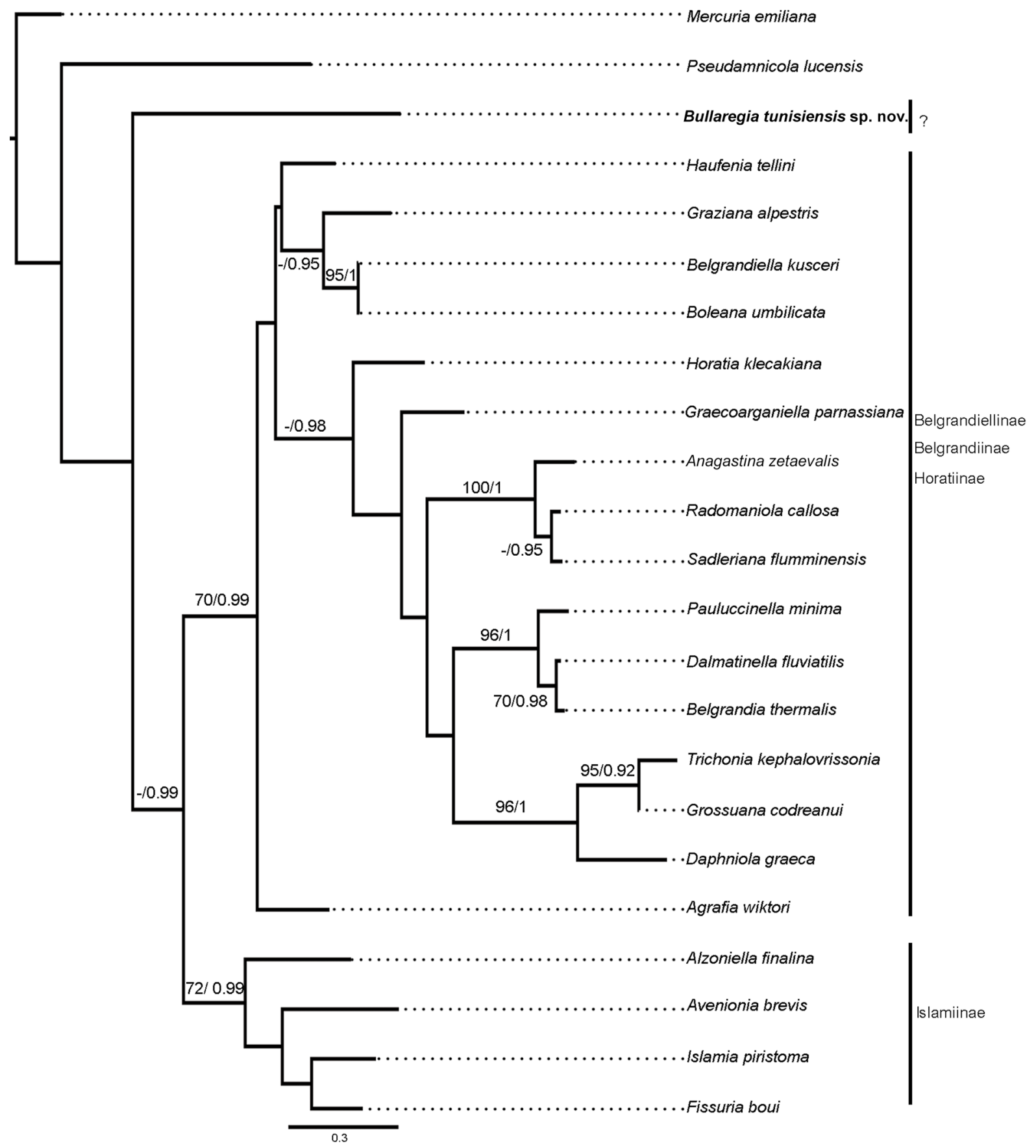

Fig. 2. Maximum likelihood inference based on COI dataset. Bootstrap values and BPP's are given when $\geq 70 \%$ and 0.90 , respectively. Black bars on the right indicate subfamily assignments. Scale bar: expected change per site. 


\section{Type material}

\section{Holotype}

TUNISIA: collected in Aïn Gnaa spring, Province Jendouba, 9 May 2008, leg. Khalloufi (MNCN $15.05 / 60177 \mathrm{H})$.

\section{Paratypes}

TUNISIA: Aïn Gnaa spring, 10 ex., 9 May 2008, leg. Khalloufi (MNCN 15.05/60177P); spring in Djebba, 15 Jun. 2009, leg Khalloufi (MNCN 15.05/60178).

\section{Type locality}

TUNISIA: Aïn Gnaa spring (Bulla-régia), Province Jendouba, 36.5583 N, 8.74667 E, Alt. 206 m a.s.1.

\section{Other material examined}

TUNISIA: 56 ex. in ethanol 95\% (30 dissected), province of Jendouba, Aïn Gnaa spring (Bulla-régia), $36.5583 \mathrm{~N}, 8.74667 \mathrm{E}, 206 \mathrm{~m}$ a.s.1., 9 May 2008; 15 ex. in ethanol 95\% (10 dissected), province of Jendouba, spring in Djebba, 36.47125 N, 9.0997223 E, 342 m a.s.1., 2 Feb. 2009; 45 ex. in ethanol 95\% (35 dissected), province of Béja, 15 Jun. 2009.

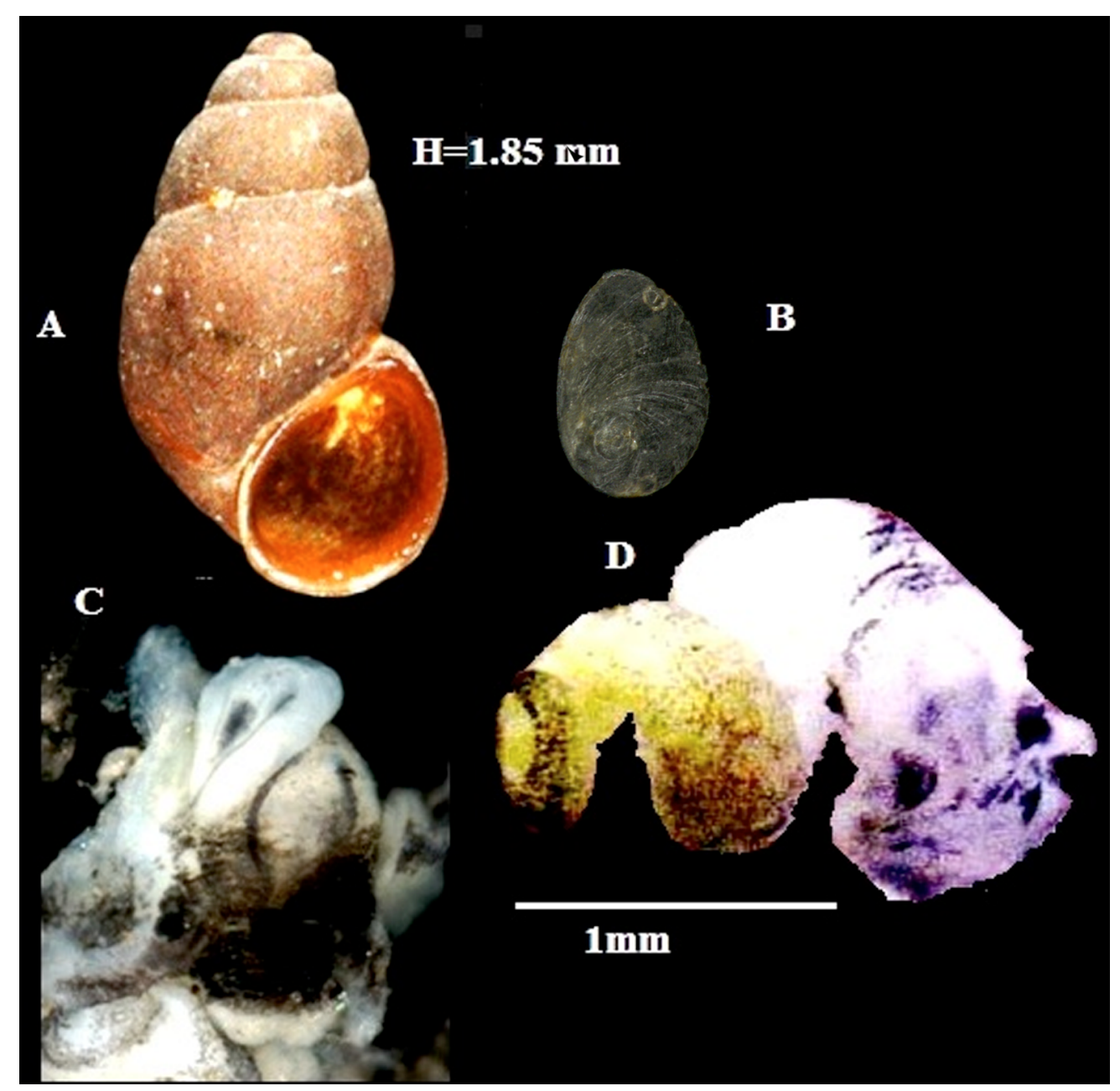

Fig. 3. Bullaregia tunisiensis gen. et sp. nov. A. Shell (holotype). B. Operculum. C. Head and penis. D. Coiled body. 


\section{Description}

MeAsurements. Holotype: $\mathrm{H}=1.85 \mathrm{~mm}, \mathrm{~W}=1.06 \mathrm{~mm}, \mathrm{AH}=0.73 \mathrm{~mm}, \mathrm{AW}=0.79 \mathrm{~mm}$

SHELL. Ovate-conic, brown-yellowish, with 4-4.5 whorls (Fig. 3A); mean SH $1.6 \mathrm{~mm} \pm 0.35 \mathrm{~mm}$ and SW $0.91 \pm 0.15 \mathrm{~mm}$; maximum height is $2.1 \mathrm{~mm}$; mean SL / SW $1.75 \pm 0.2$; body whorl about $2 / 3$ total length; rest of whorls slightly convex with deep sutures; aperture about $45 \%$ of shell height, complete, pyriform, slightly angled at the top and attached to body whorl; thin inner peristome but thicker than outer lip; peristome margin straight; umbilicus narrow.

OperCULum. With ca 2 whorls (Fig. 3B) and muscle attachment area oval and located near the nucleus.

RADULA. Intermediate length ( $20 \%$ total maximum shell length), bearing about 80 rows of teeth; central tooth formula 6-C-6/1-1 (Fig. 4A-B); lateral teeth formula 5-C-5; inner marginal teeth having 30-35 sharp cusps; outer marginal teeth having 25-30 sharp cusps (Fig. 4C).

Pigmentation and anatomy. Visceral coil yellowish, showing by transparency the gonad; traces of pigment on pallial roof, visceral coil, anterior edge of mantle, foot and light pigment between tentacles (Fig. 3D). Black eyes surrounded by brownish pigment. Snout with medium distal lobation. Tentacles parallel-side, distal end nonexpanded. Ctenidium with 9-13 gill filaments; osphradium whitish, elongate, two times longer than wide and approximate opposite middle of ctenidium. Stomach with large gastric (posterior) caecum.

Male gentialia. Penis strap-like with a well-developed glandular lobe on the outer edge, $33 \%$ total penis length; glandular lobe strap-like and with a short duct; distal end of penis tapered, dark pigmented (Figs 3C, 5A). The penis has distinct basal and distal portions. The distal portion is smooth, with tapered end and variable in length. The basal portion is cylindrical and folded. Prostate gland, close, bean-shaped in outline, oval in section, and about twice as long as wide $(0.45 \mathrm{~mm} / 0.25 \mathrm{~mm})$. Posterior vas deferens forms the seminal vesicle with many loops. It is well-developed (about $4 \mathrm{~mm}$ in length and $0.1 \mathrm{~mm}$ in section) and strongly undulating, coiling immediately after it emerges from the testis and extending over the posterior and middle part of the stomach. The pallial vas deferens is a straight and narrow tube unciliated, entering postero-ventral portion of gland and exiting from its anterior end.

Female genitalia. Ovary simple with stalked lobes. Pallial oviduct bearing an ovoid bursa copulatrix with a duct longer than its length; unpigmented renal oviduct, with a pouch at the end of the coiled section; two seminal receptacles; SR1 elongate with a short duct, close to the insertion point of the
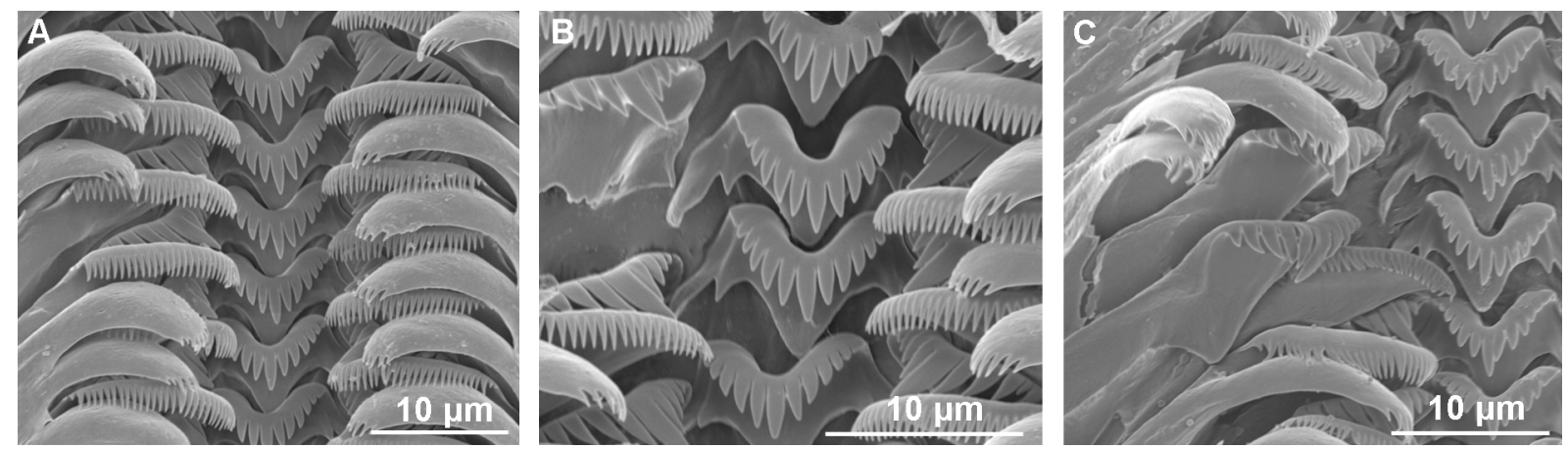

Fig. 4. Radula of Bullaregia tunisiensis gen. et sp. nov. from a spring in Djebba, Tunisia. A. Rows of teeth of the radula. B. Detail of central teeth. C. Detail of lateral and marginal teeth. 
bursal duct to the renal oviduct; SR2 globular, less developed and sessile, positioned near antero-ventral edge of bursa (Fig. 5B).

\section{Remarks}

Populations of this species from the Aïn Gnaa and Djebba springs vary only scarcely in terms of morphology and anatomy. In specimens from the Aïn Gnaa spring, the shell is generally more slender and has deeper sutures and a sharper protoconch. The portion of the vas deferens, forming the seminal vesicle, is more coiled and more developed. Pigmentation in the Djebba spring specimens is more intense, especially in the mantle and distal portion of the penis. Individuals from these populations are conchologically differentiated from similar regional species, such as Pseudamnicola meluzzi Boeters, 1976 and P. conovula (Frauenfeld, 1863), by their smaller and slender shell, a taller penultimate whorl relative to remaining whorls and by an aperture pyriform, angled on top.

Representatives of these two populations featured a similar shell morphology as the specimens from Algeria deposited in the Muséum national d'Histoire naturelle, Paris (MNHN). These specimens were earlier identified as Amnicola seminium (Morelet, 1857) by Bourguignat. However, this species, illustrated by Morelet in the original description (Morelet 1857, pl. XII fig. 10) differs from the Algerian specimens deposited in the MNHN. Based on Morelet's illustration (1857: pl. XII Fig. 10), the type of A. seminium has a larger body whorl, a shorter penultimate whorl and a rounder aperture (resembling Pseudamnicola) than the MNHN specimens. Thus, these Algerian snails could have been misidentified. Based on common shell features shared by these specimens and Bullaregia gen. nov., such as ovateconic shape, tall penultimate whorl, aperture angled on top and closed umbilicus, they could be assigned to this new genus.

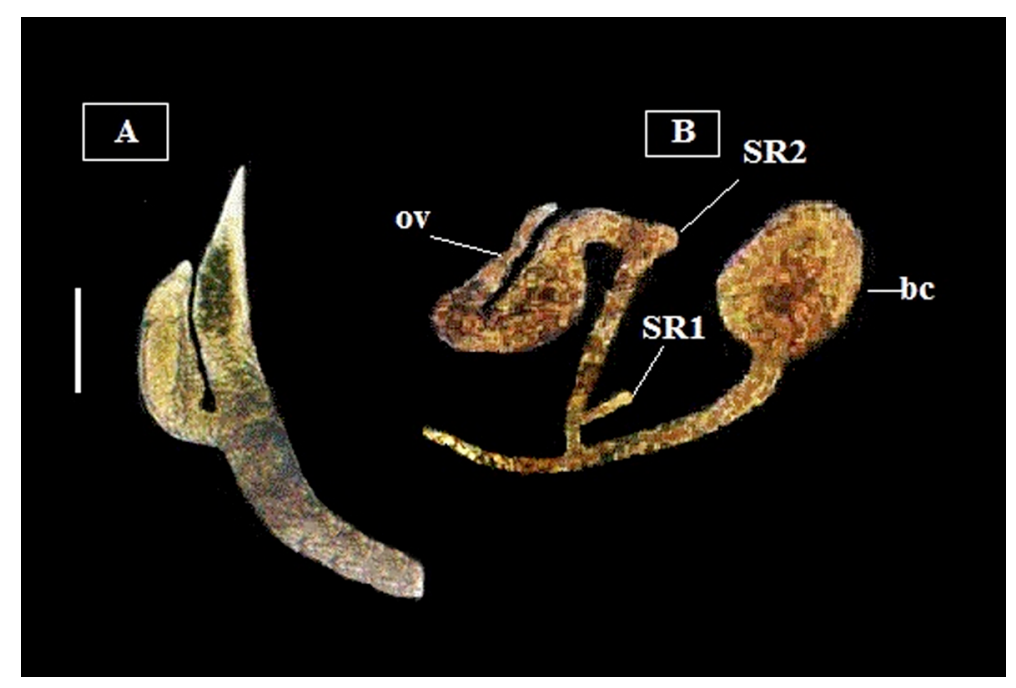

Fig. 5. Genitalia of Bullaregia tunisiensis gen. et sp. nov. A. Penis (paratype). B. Distal female genitalia. Abbreviations: $\mathrm{bc}=$ bursa copulatrix; ov = renal oviduct; $\mathrm{SR}=$ seminal receptacle. Scale bar $0.1 \mathrm{~mm}$.

\section{Discussion}

The freshwater gastropod diversity of some geographical regions including Europe, North America and Australasia, has been better explored than that of others (Strong et al. 2008). Our discovery here of Bullaregia gen. nov. calls for more field work in North Africa to further our understanding of global species richness, distribution and evolutionary patterns in hydrobiid clades. The new springsnail described 
shows a small distribution range. This means, it could be the second Hydrobiidae genus endemic to North Africa (after Heideella, see Bodon et al. 1999). Although the total number of African hydrobiid species remains unknown (Brown 1994), taxonomic revisions of the North African Hydrobiidae sensu lato have recognized 13 genera, including Bullaregia gen. nov. discovered herein. In total, 37 species belonging to these and other undiscovered hydrobiid genera are considered threatened in North Africa (Van Damme et al. 2010). Pollution, habitat loss and an ever drier climate are the factors thought to have most contributed to the decline of freshwater molluses in North Africa. In addition, numerous Tunisian freshwater wells are presently at risk of salinization (Van Damme et al. 2010).

However, assignments of African taxa to European genera, often based on shell descriptions only, may be erroneous. For example, the presence of Belgrandiella in North Africa is still uncertain. Its first record in North Africa was detected through the synonymization of the African genus Maresia with Belgrandiella (suggested by Boeters 1988). Bourguignat (1877) described the genus Maresia from Algeria and designated Hydrobia dolichia Bourguignat, 1864 as the type species. Nonetheless, Kabat \& Hershler (1993) stated that Bourguignat's Maresia is a junior homonym, and thus invalid as a mollusc. Additionally, some Maresia species, including the type species, M. dolichia, or M. nana (Bourguignat, 1864), have been ascribed to the genus Heideella (García et al. 2010). There is therefore no sound evidence confirming the presence of Belgrandiella in North Africa.

Despite their closely resembling shell shape, the high anatomical and molecular variation observed between Bullaregia gen. nov. and other European hydrobiids (e.g., Belgrandiella or Terranigra) reveals these genera as different entities. Our phylogenetic analyses, which included sequences of species of the subfamilies Belgrandiellinae, Islamiinae and Horatiinae, did not cluster Bullaregia gen. nov. within any of these groups (Fig. 2). Hence, pending more complete phylogenies for this family, Bullaregia gen. nov. could be a new hydrobiid subfamily distinguishable mainly by a dorsal glandular lobe on the penis and the joint presence of seminal receptacles and a pouch in the renal oviduct. Glandular ornaments on the penis have also been observed in males of the European genus Agrafia Szarowska \& Falniowski, 2011 (see Szarowska \& Falniowski 2011) and the American subfamily Nymphophilinae (see Hershler et al. 2003; Hershler \& Liu 2009; Hershler et al. 2011, among others). However, in the absence of a well supported relationship, this feature could be a synapomorphy of these clades or a result of convergent evolution. More comprehensive molecular studies will help resolve the phylogenetic relationship of this newly discovered hydrobiid clade. This type of information is indeed essential to unveil the first evolutionary events that gave rise to the major clades of the family Hydrobiidae.

\section{Acknowledgements}

We would like to thank Peter Glöer for his contribution in comparing the Tunisian species with Amnicola seminium specimens deposited in MNHN and for his suggestions during the preparation of this paper. Dr. Boeters assisted with the comparison of our samples with specimens from Algeria in his own collection; Barbara Hoenig and Sabine Agel (Imaging Unit, Biomedical Research Centre Seltersberg, Justus Liebig University, Giessen) helped with the ESEM photomicrographs of the radula. The English was reviewed by Ana Burton. The manuscript was improved by the comments and suggestions of an anonymous reviewer and section editor Kurt Jordaens. This study was supported by a fellowship of the postdoctoral program Just'us (Junior Science and Teaching Units, Justus Liebig University, Giessen) granted to D.D.

\section{References}

Akaike H. 1974. A new look at the statistical model identification. IEEE Transactions on Automatic Control 19: 716-723. https://doi.org/10.1109/TAC.1974.1100705

Bodon M., Ghamizi M. \& Giusti F. 1999. The Moroccan stygobiont genus Heideella (Gastropoda: Prosobranchia: Hydrobiidae). Basteria 63: 89-105. 
Boeters H.D. 1976. Hydrobiidae Tunesiens. Archiv für Molluskenkunde 107 (1-3): 89-105.

Boeters H.D. 1988. Westeuropäische Moitessieriidae und Hydrobiidae in Spanien und Portugal (Gastropoda: Prosobranchia). Archiv für Molluskenkunde 118: 181-261.

Bourguignat J.R. 1860. Malacologie terrestre et fluviatile de la Bretagne. J.B. Baillière, Paris.

Bourguignat J.R. 1864. Malacologie de l'Algérie. Histoire naturelle des animaux Mollusques terrestres et fluviatiles. Challamed Bastid, Paris.

Bourguignat J.R. 1877 Descriptions de deux nouveaux genres algériens, suivies d'une classification des familles et des genres de mollusques terrestres et fluviatiles du système européen. Extrait de la Société des Sciences physiques et naturelles de Toulouse, Imprimerie Louis et Jean-Matthieu, Douladoure.

Brown D.S. 1994. Freshwater snails of Africa and their medical importance. Second revised edition, Taylor \& Francis, London.

Charni M., Harrath A., Sluys R., Tekaya S. \& Zghal F. 2004. The freshwater planarian Dugesia sicula Lepori, 1948 (Platyhelminthes, Tricladida) in Tunisia: ecology, karyology and morphology. Hydrobiologia 517: 161-170. https://doi.org/10.1023/B:HYDR.0000027344.07747.f7

Debeaux O. 1863. Notice sur quelques Mollusques nouveaux, ou peu connus, de la grande Kabylie. Journal de Conchyliologie 11: 10-21.

Delicado D., Pešić V. \& Glöer P. 2016. Unraveling a new lineage of Hydrobiidae genera (Caenogastropoda: Truncatelloidea) from the Ponto-Caspian region. European Journal of Taxonomy 208: 1-29. https://doi. org/10.5852/ejt.2016.208

Falniowski A. \& Szarowska M. 2011. A new genus and new species of valvatiform hydrobiid (Rissooidea; Caenogastropoda) from Greece. Molluscan Research 31 (3): 189-199.

Falniowski A. \& Szarowska M. 2012. Phylogenetic position of Boleana umbilicata (Kuščer, 1932) (Caenogastropoda: Rissooidea). Folia Malacologica 20 (4): 265-270. https://doi.org/10.2478/v10125$\underline{012-0022-2}$

Falniowski A. \& Szarowska M. 2013. Phylogenetic relationships of Dalmatinella fluviatilis Radoman, 1973 (Caenogastropoda: Rissooidea). Folia Malacologica 21 (1): 1-7. https://doi.org/10.12657/ folmal.021.001

Felsenstein J. 1981. Evolutionary trees from DNA sequences: A maximum likelihood approach. Journal of Molecular Evolution 17: 368-376. https://doi.org/10.1007/BF01734359

Felsenstein J. 1985. Confidence limits on phylogenies: An approach using the bootstrap. Evolution 39: 783. https://doi.org/10.2307/2408678

Folmer O., Black M., Hoeh W., Lutz R. \& Vrijenhoek R. 1994. DNA primers for amplification of mitochondrial cytochrome c oxidase subunit I from diverse metazoan invertebrates. Molecular Marine Biology and Biotechnology 3: 294-299.

García N., Cuttelod A. \& Abdul Malak D. 2010. The Status and Distribution of Freshwater Biodiversity in Northern Africa. IUCN, Gland, Switzerland, UK; Malaga, Spain.

Ghamizi M., Bodon M., Boulal M. \& Guisti F. 1999. Atebbania bernasconii, a new genus and species from subterranean waters of the Tiznit plain, southern Morocco (Gastropoda: Hydrobiidae). Journal of Molluscan Studies 65: 89-98. https://doi.org/10.1093/mollus/65.1.89

Glöer P., Boeters H.D. \& Pešić V. 2014. Freshwater molluscs of Kyrgyzstan with description of one new genus and species (Mollusca: Gastropoda). Folia Malacologica 22 (2): 73-81. https://doi.org/10.12657/ folmal.022.009 
Harrath A., Charni M., Sluys R., Zghal F. \& Tekaya S. 2004. Ecology and distribution of the freshwater planarian Schmidtea mediterranea in Tunisia. Italian Journal of Zoology 71: 233-236. https://doi. org/10.1080/11250000409356577

Harrath A., Tekaya S. \& Zghal F. 2001. Biodiversity of freshwater planarians (Turbellaria, Tricladida) from Tunisia. Bulletin de la Société zoologique de France 126 (1-2): 228-229.

Hershler R. \& Liu H.P. 2009. New species and records of Pyrgulopsis (Gastropoda: Hydrobiidae) from the Snake River basin, southeastern Oregon: further delineation of a highly imperiled fauna. Zootaxa 2006: 1-22.

Hershler R. \& Ponder W.F. 1998. A review of the morphological characters of hydrobioid snails. Smithsonian Contributions to Zoology 600: 1-55.

Hershler R., Liu H.P. \& Thompson F.G. 2003. Phylogenetic relationships of North American nymphophiline gastropods based on mitochondrial DNA sequences. Zoologica Scripta 32 (4): 357-366. https://doi.org/10.1046/j.1463-6409.2003.00115.x

Hershler R., Thompson F.G. \& Liu H.P. 2011. A large range extension and molecular phylogenetic analysis of the monotypic North American aquatic gastropod genus Cincinnatia (Hydrobiidae). Journal of Molluscan Studies 77 (3): 232-240. https://doi.org/10.1093/mollus/eyr008

Huelsenbeck J.P. 2000. MrBayes: Bayesian Inference of Phylogeny. NCBI, New York.

Huelsenbeck J.P. \& Ronquist F. 2001. MRBAYES: Bayesian inference of phylogenetic trees. Bioinformatics 17: 754-755. https://doi.org/10.1093/bioinformatics/17.8.754

Hurvich C.M. \& Tsai C.L. 1989. Regression and time series model selection in small samples. Biometrikam 76: 297-307 https://doi.org/10.1093/biomet/76.2.297

Issel A. 1880. Molluschi terrestri e d'acqua dolce viventi e fossili della Tunisia. Annali del Museo Genova XV, Instituto Sordo-Muti, Genova.

Kabat A.R. \& Hershler R. 1993. The Prosobranch snail family Hydrobiidae (Gastropoda: Rissooidea): Review of classification and supraspecific taxa. Smithsonian Contributions to Zoology 547: 1-94. https://doi.org/10.5479/si.00810282.547

Kristensen T.K. 1985. Guide pratique des Gastéropodes d'eau douce Africains. Espèces présentes en Afrique du Nord-Ouest. Charlottenlund, Denmark Danish Bilharziasis Laboratory 7: 1-21.

Lanfear R., Calcott B., Ho S.Y.W. \& Guindon S. 2012. PartitionFinder: combined selection of partitioning schemes and substitution models for phylogenetic analyses. Molecular Biology and Evolution 29 (6): 1695-1701. https://doi.org/10.1093/molbev/mss020

Letourneux A. \& Bourguignat J.R. 1887. Prodrome de la malacologie terrestre et flviatile de la Tunisie. Exploration scientifique de la Tunisie, Zoologie, Malacologie. Imprimerie nationale, Paris.

Morelet A. 1857. Appendice à la conchyliologie de l'Algérie; voyage de M. Grasset à EI-Aghouat. Journal de Conchyliologie 6: 369-376.

Pallary P. 1921. Faune malacologique du Grand Atlas. Journal de Conchyliologie 66: 81-217.

Pallary P. 1923. Faune malacologique des eaux douces de la Tunisie. Archives des Instituts Pasteur de l'Afrique du Nord 1: 22-47.

Radoman P. 1983. Hydrobioidea a Superfamily of Prosobranchia (Gastropoda): Systematics. Serbian Academy of Sciences and Arts, Belgrade. 
Schreiber K., Hauffe T., Albrecht C. \& Wilke T. 2012. The role of barriers and gradients in differentiation processes of pyrgulinid microgastropods of Lake Ohrid. Hydrobiologia 682: 61-73. https://doi. org/10.1007/s10750-011-0864-4

Seurat E.G. 1921. Faune des Eaux continentales de la Berbérie. Travaux du Laboratoire de Zoologie Appliquée, Faculté des Sciences, Université d'Alger, Algeria.

Seurat E.G. 1934 Formations littorales et estuaires de la Syrte mineure (golfe de Gabès). Bulletin de la Station océanographique de Salambo, Tunisia.

Stamatakis A. 2014. RAxML Version 8: A tool for Phylogenetic Analysis and Post-Analysis of Large Phylogenies. Bioinformatics 30 (9): 1312-1313. https://doi.org/10.1093/bioinformatics/btu033

Strong E., Gargominy O., Ponder W.F. \& Bouchet P. 2008. Global diversity of gastropods (Gastropoda; Mollusca) in freshwater. Hydrobiologia 595: 149-166. https://doi.org/10.1007/s10750-007-9012-6

Sugiura N. 1978. Further analysis of the data by Akaike's information criterion and the finite corrections. Communications in Statistics - Theory and Methods A 7: 13-26. https://dx.doi. org $/ 10.1080 / 03610927808827599$

Swofford D.L. 2002. PAUP*. Phylogenetic analysis using parsimony (*and other methods). Sinauer Associates, Sunderland, Massachusetts.

Szarowska M. 2006. Molecular phylogeny, systematics and morphological character evolution in the Balkan Rissooidea (Caenogastropoda). Folia Malacologica 14: 99-168. https://doi.org/10.12657/ folmal.014.014

Szarowska M. \& Falniowski A. 2011. An unusual, flagellum-bearing hydrobiid snail (Gastropoda: Rissooidea: Hydrobiidae) from Greece, with descriptions of a new genus and a new species. Journal of Natural History 45 (35-36): 2231-2246. https://doi.org/10.1080/00222933.2011.591067

Szarowska M. \& Falniowski A. 2014. Horatia Bourguignat, 1887: Is this genus really phylogenetically very close to Radomaniola Szarowska, 2006 (Caenogastropoda: Truncatelloidea)? Folia Malacologica 22: 31-39. https://doi.org/10.12657/folmal.022.003

Szarowska M., Grzmil P., Falniowski A. \& Sirbu I. 2007. Grossuana codreanui (Grossu, 1946) and the phylogenetic relationships of the East Balkan genus Grossuana (Radoman, 1973) (Gastropoda: Rissooidea). Hydrobiologia 579: 379-391. https://doi.org/10.1007/s10750-006-0530-4

Tamura K. \& Nei M. 1993. Estimation of the number of nucleotide substitutions in the control region of mitochondrial DNA in humans and chimpanzees. Molecular Biology and Evolution 10: 512-526.

Tavaré S. 1986. Some probabilistic and statistical problems in the analysis of DNA sequences. In: Miura R.M. (ed.) Some mathematical questions in biology - DNA sequence analysis: 57-86. Lectures on Mathematics in the Life Sciences, Vol. 17. American Mathematical Society, Providence, RI.

Toumi H., Béjaoui M. \& Boumaiza M. 2013. Contribution to the ecological study of epigean Cladocera and Copepoda (Cyclopoida) from groundwater in Northern Tunisia. Nature \& Technology Journal. CEnvironmental Sciences 8: 12-18.

Van Damme D. 1984. The freshwater Mollusca of Northern Africa. Distribution, biogeography and palaeoecology. Developments in Hydrobiology 25: 1-164.

Van Damme D., Ghamizi M., Soliman G., McIvor A. \& Seddon M.B. 2010. The status and distribution of freshwater molluscs. In: García N., Cuttelod A. \& Abdul Malak D. (eds) The status and distribution of freshwater biodiversity in Northern Africa: 30-50. IUCN, Gland, Switzerland; Cambridge, UK; Malaga, Spain. 
Wilke T. \& Davis G.M. 2000. Infraspecific mitochondrial sequence diversity in Hydrobia ulvae and Hydrobia ventrosa (Hydrobiidae: Rissooidea: Gastropoda): Do their different life histories affect biogeographic patterns and gene flow? Biological Journal of the Linnean Society 70: 89-105. https:// doi.org/10.1111/j.1095-8312.2000.tb00202.x

Wilke T., Davis G.M., Falniowski A., Giusti F., Bodon M. \& Szarowska M. 2001. Molecular systematics of Hydrobiidae (Mollusca: Gastropoda: Rissooidea): testing monophyly and phylogenetic relationships. Proceedings of the Academy of Natural Sciences of Philadelphia 151:1-21. https://doi.org/10.1635/00973157(2001)151[0001:MSOHMG]2.0.CO;2

Wilke T., Davis G.M., Qiu D.C. \& Spear R.C. 2006. Extreme mitochondrial sequence diversity in the intermediate schistosomiasis host Oncomelania hupensis robertsoni: another case of ancestral polymorphism? Malacologia 48: 143-157.

Wilke T., Haase M., Hershler R., Liu H.P., Misof B. \& Ponder W. 2013. Pushing short DNA fragments to the limit: Phylogenetic relationships of 'hydrobioid' gastropods (Caenogastropoda: Rissooidea). Molecular Phylogenetics and Evolution 66: 715-736. https://doi.org/10.1016/j.ympev.2012.10.025

Zhang Z., Schwartz S., Wagner L. \& Miller W. 2000. A greedy algorithm for aligning DNA sequences. Journal of Computational Biology 7 (1-2): 203-214. https://doi.org/10.1089/10665270050081478

Manuscript received: 12 September 2016

Manuscript acepted: 14 December 2016

Published on: 9 June 2017

Topic editor: Rudy Jocqué

Section editor: Kurt Jordaens

Desk editor: Pepe Fernández

Printed versions of all papers are also deposited in the libraries of the institutes that are members of the EJT consortium: Muséum national d'Histoire naturelle, Paris, France; Botanic Garden Meise, Belgium; Royal Museum for Central Africa, Tervuren, Belgium; Natural History Museum, London, United Kingdom; Royal Belgian Institute of Natural Sciences, Brussels, Belgium; Natural History Museum of Denmark, Copenhagen, Denmark; Naturalis Biodiversity Center, Leiden, the Netherlands; Museo Nacional de Ciencias Naturales-CSIC, Madrid, Spain; Real Jardín Botánico de Madrid CSIC, Spain. 